\title{
Kulturowe uwarunkowania nazw ulic — tradycja i zmiana
}

W nurt badań kulturowych wpisuje się zarówno problematyka sposobu nadawania nazw ulicom i jego uwarunkowań, jak i zagadnienie przyczyn zmian nazw istniejących. Artykuł dotyczy problematyki kulturowych uwarunkowań w nazewnictwie ulic oraz zmian w metodzie i zakresie badań onomastycznych. Literatura onomastyczna dotycząca nazw ulic miast jest bardzo bogata. Opisy nazw ulic były i są przedmiotem wielu artykułów i monografii (zob. np. Buczyński 1966; Antkowiak 1970; Handke 1970; Supranowicz 1995; Jancewicz, Smółka 2000; Myszka, Wisz 2012). Początkowo nazwy ulic pojawiały się głównie w opracowaniach historyków, zapewne dlatego, że mówią one o historii miast i są cenną pomocą $\mathrm{w}$ badaniach historycznych. Pierwsze prace onomastyczne dotyczące nazw ulic, które skupiają się na ich stronie językowej, etymologii i strukturze, pojawiły się na początku lat sześćdziesiątych XX wieku i publikuje się ich coraz więcej. Historia nadawania nazw ulicom, motywy nominacji, związek nazwy z desygnatem, stan badań nad nazewnictwem ulic w Polsce zostały omówione w części teoretyczno-syntetyzującej monografii ulic Rzeszowa autorstwa językoznawcy Agnieszki Myszki i historyka Piotra Wisza (2012, s. 16-27).

Rozwój badań nazewnictwa miejskiego przyczynił się do opracowania odpowiedniej metodologii i terminologii. Nastąpiły także zmiany w zakresie badań onomastycznych, które początkowo skupiały się na analizie i opisie nazw miejscowych oraz osobowych, a głównym przedmiotem ich badań były toponimia $\mathrm{i}$ antroponimia. Wiele miejsca poświęcono zdefiniowaniu samego terminu nazwa własna i odróżnieniu go od wyrazu pospolitego oraz klasyfikacji nazw własnych. $\mathrm{Z}$ czasem zakres badań onomastycznych zaczął się poszerzać o nazwy wód, gór, zwierząat, ulic i placów, towarów, sklepów itd. Wprowadzono i uściślono terminy określające typ i przedmiot tych badań. Toponimy (grec. 'topos' = miejsce) to nazwy geograficzne. Wśród nich wyróżnia się: oronimy (grec. 'oros' = góra) nazwy górskie; mikrotoponimy - nazwy terenowe: pól i ich części, łąk, bagien, 
wzgórz, lasów, dróg itp.; nazwy miejscowe: miast i wsi; hydronimy (grec. 'hydros' = woda) - nazwy wodne: rzek, strumieni, kanałów, rowów, jezior oraz nazwy przybrzeżne. Nazwami miejskimi zajmuje się toponimia miejska, zamiennie nazywana urbanonimiq. Przedmiot jej badań stanowią urbanonimy (łac. 'urbanos' = miejski), czyli nazwy własne obiektów i miejsc znajdujących się w obrębie miasta. Wśród urbanonimów wyróżnia się: plateonimy (łac. 'platea' = ulica) - nazwy ulic i hodonimy (grec. 'hodos' = droga) — nazwy dróg i przejazdów.

$\mathrm{W}$ opisach nazw stosowano różne metody i różne klasyfikacje zarówno strukturalne, jak i semantyczne ${ }^{1}$. Najpopularniejszą typologią nazewnictwa miejskiego stosowaną przez wielu badaczy jest klasyfikacja semantyczna opracowana przez Kwirynę Handke (1992) ${ }^{2}$. Zdarza się jednak, że przyporządkowanie nazwy do danej grupy nie jest jednoznaczne, zależy bowiem od motywacji, np. Bernardyńska może pochodzić od nazwy zakonu lub od nazwy jego siedziby.

W badaniach onomastycznych na początku XXI wieku wyodrębniono onomastykę kulturową. Pojęcie to pojawiło się w artykule Roberta Mrózka (2004) o nazwach własnych jako przedmiocie badawczym onomastyki. Szerzej onomastyką kulturową zajmowała się Ewa Rzetelska-Feleszko (2007). W artykule Onomastyka kulturowa podkreśla ona, że takie podejście badawcze pozwala dostrzec „W nazwach własnych przekaźniki rozmaitych treści i form kultury”, poszerzając wiedzę o związkach nazewnictwa z rzeczywistością w przeszłości i teraźniejszości oraz o funkcjach nazw własnych, ponieważ uwzględnia także inne funkcje nazwy, nie tylko identyfikacyjną, która wskazuje na obiekt (Rzetelska-Feleszko 2007, s. 58-59). Onomastykę kulturową autorka uważa za jeden z kierunków lingwistyki kulturowej. Zastosowanie kulturowego spojrzenia na nazwy ulic pomaga w odczytaniu motywacji nazwy, a także w poznaniu zjawisk kultury materialnej i duchowej, wydarzeń historycznych, osób ważnych dla mieszkańców danego miasta w okresie nadawania lub zmiany nazwy. Podejście kulturowe w opisie nazw ulic zastosowała Ewa Oronowicz-Kida (2014), badając oficjalne nazwy ulic we wsiach województwa podkarpackiego. Autorka poświęca oddzielne rozdziały motywacji opisywanych nazw i inspiracjom kulturowym mającym wpływ na nazwanie ulicy. Jak pisze Handke (2005, s. 284), na świecie są różne systemy oznaczania obiektów w przestrzeni miasta; w Europie najpowszechniejszy jest system werbalny, w Stanach Zjednoczonych system numeryczny, z kolei w Japonii — graficzny. Badaczka pisze, że „Nazewnictwo miast europejskich intensywnie zaczęło się rozwijać w dobie średniowiecza, ale archetypy nazw obiektów miejskich wykształciły się w starożytności, głównie w Rzymie" (Handke 2005, s. 284; zob też Myszka, Wisz 2012, s. 16-18).

${ }^{1}$ Metodologii badań nazw miejskich został poświęcony m.in. zbiór artykułów Nazewnictwo miejskie pod redakcją Stanisława Urbańczyka (1998).

2 Klasyfikację tę zastosowałam w tabeli zamieszczonej w dalszej części artykułu, rozszerzając ją w grupie nazw topograficznych o podział Franciszka Nowaka (1989, s. 142). 
Podstawę materiałową moich rozważań stanowią nazwy ulic w trzech miastach Małopolski: Bochni, Dąbrowie Tarnowskiej i Tarnowie. Nazwy omawianych ulic pochodzą z internetowych spisów i planów tych miast, weryfikowane były przeze mnie także w tych miastach. Ponadto nazwy ulic tarnowskich zostały dodatkowo porównane ze słownikami nazw ulic Tarnowa zamieszczonymi w pracach Barbary Jewuły i Ksymeny Dominiewskiej ${ }^{3}$.

Miasta te leżą blisko siebie: Bochnia ok. $40 \mathrm{~km}$ na zachód od Tarnowa, a Dąbrowa Tarnowska ok. $20 \mathrm{~km}$ na północ. W podziale administracyjnym obowiązującym w latach 1975-1998 należały do województwa tarnowskiego.

Są to miasta o długiej historii. Pierwsze wzmianki o Bochni pochodzą z 1198, o Tarnowie z 1309, a o Dąbrowie Tarnowskiej z 1326 roku. Miasta te lokowane były: Bochnia w 1253, Tarnów w 1330, Dąbrowa Tarnowska w 1422 roku. Bochnia jest więc najstarszym z nich. Na jej znaczenie wpłynęło wydobycie złóż soli kamiennej. Najmłodszym i najmniejszym miastem jest Dąbrowa Tarnowska, największym zaś Tarnów, który do roku 1787 był miastem prywatnym i należał kolejno do rodów: Leliwitów Tarnowskich, Ostrogskich i Sanguszków. W 1818 roku Tarnów został zaliczony do grupy miast cesarskich. Po II wojnie światowej był miastem przemysłowym i stolicą województwa w latach 1975-2000. Od 1786 jest stolicą diecezji tarnowskiej, z przerwą w latach 1795-1826. W nowej rzeczywistości społeczno-politycznej miasto straciło swój charakter przemysłowy, ale pozostało ośrodkiem kulturalnym i miejscem wielu wydarzeń artystycznych do najważniejszych należy Ogólnopolski Festiwal Komedii „Talia”. W tutejszym Muzeum Etnograficznym znajduje się pierwsza w Europie stała ekspozycja poświęcona kulturze i historii Romów. Wszystkie te fakty znalazły swoje odbicie w nazewnictwie ulic i placów.

Nazwy miejskie w Polsce pojawiały się zwykle po nadaniu praw miejskich. Jak podaje Handke, pierwsze nazwy ulic Warszawy lokowanej w XIII wieku pojawiają się w dokumentach z początku XV wieku, Krakowa lokowanego w XIII wieku pochodzą z dokumentów czternastowiecznych, podobnie w Poznaniu (Handke 2005, s. 285-286). Także w Bochni najwcześniej odnotowane nazwy ulic są późniejsze od lokacji (XIII wiek) i pochodzą z XV wieku. Najstarsze ulice w Bochni wymienia Stanisław Kobiela (2013, s. 9-12): Biała - 1488, Gotębia - 1486-1508, Solna Góra - 1487, Kowalska - 1528, Krakowska - 1564, Krakowskie Przedmieście - 1485, Różana - 1493, Świętokrzyska (pierwotna nazwa: Świętego Krzyża) - $1488^{4}$.

Na podstawie analizy nazw ulic w tych trzech miastach spróbuję pokazać, jak zmienia się użycie różnego typu nazw w toponimii miejskiej i czego te zmiany dotyczą, jaki typ nazw przeważał dawniej, a jaki jest stosowany obecnie. Rudolf Šrámek pisze, że każda nazwa własna służy wyróżnieniu, o tym zaś, co w danym

\footnotetext{
3 Bibliografia ważniejszych opracowań ulic Tarnowa — zob. (Data 2011).

4 Wymieniam tylko przykładowo część dawnych nazw z tych, które przetrwały do dziś.
} 
mieście zostanie wyróżnione, decydują przede wszystkim czynniki społeczne (Šrámek 2010, s. 25). Z kolei Handke zauważa, że „tylko dla części nazw zwłaszcza starszych i tworzonych spontanicznie przez mieszkańców w różnych okresach historii miasta można znaleźć uzasadnienie genetyczno-semantyczne. Pozostałe nazwy, szczególnie te, które powstały w wyniku administracyjnych działań urzędów, mają charakter wtórny - są tworzone na zasadzie powielania wcześniejszych wzorów". W związku z tym badaczka podkreśla, że przy charakterystyce i semantycznej klasyfikacji nazw miejskich ważne jest rozróżnianie nazw podstawowych, pierwotnych, wzorcowych od nazw pochodnych, wtórnych, powielających istniejące wzorce, niemających wartości realnoznaczeniowej (Handke 2005, s. 290). Zwraca także uwagę na odrębny rodzaj motywacji pamiątkowych nazw ulic wynikający z uwarunkowań historycznych, politycznych i kulturalnych oraz dążeń mieszkańców, którzy nadają nazwy ulicom dla uczczenia ważnych postaci, instytucji, wydarzeń, faktów historycznych (Handke 2005, s. 291).

Z dotychczasowych badań (zob. m.in. Handke 1970, 1992, 2005; Myszka, Wisz 2012, s. 17-22) wynika, że nazwy ulic i placów pierwotnie związane były z topografią, odnosily się do: położenia, wyglądu nazywanego obiektu, np.: Stawki, Dluga, Krótka; kierunku, np.: Opolska — wiodąca w stronę Opola, w kierunku pól - Polna; rodzaju wykonywanej czynności, np.: Szewska, Garbarska, Laciarska, Nożownicza; stanowisk społecznych i pochodzenia mieszkańców, np.: Poselska, Rybacka, Żydowska; funkcji miejsca w osadzie, np. Cmentarna. Do najpopularniejszych należały nazwy topograficzne wskazujące na położenie ulicy oraz nazwy kierunkowe pochodzące od nazw miejscowości. Później pojawiły się nazwy lokalizujące wyróżniające się budowle, np.: Fabryczna, Bernardyńska, Franciszkańska, Kapitulna, Klasztorna, Warsztatowa. Nazwy pamiątkowe pochodzące od nazw osobowych dawniej upamiętniały głównie fundatorów, budowniczych ulic, potem także osoby zasłużone dla miasta, pochodzące $\mathrm{z}$ danego miasta, osoby znane i ważne w kraju. W XX wieku do tej grupy doszły nazwy odapelatywne i upamiętniające ważne wydarzenia historyczne, miejsca i daty. Z kolei nazwy charakteryzujące wskazujące na cechę ulicy były początkowo stosunkowo rzadkie. Jeśli idzie o motywację, w średniowieczu popularna była motywacja tzw. posesywna. Najczęściej tworzono nazwy od apelatywnych określeń grup zawodowych, od narodowości, zgromadzeń, wyznań. Następną grupę nazw stanowią nazwy z motywacją kultową, które tworzone były przede wszystkim od imion świętych lub od kościołów pod wezwaniem danego świętego. Wciąż powstają nazwy lokalizujące i kierunkowe, o czym świadczyć może wynik omówionego dalej konkursu na nazwę ulicy w Łuczycach pod Krakowem, jednak są one coraz rzadsze. Obecnie nazwy ulic nadawane są administracyjnie przez urzędy lub rady miast i gmin, także mieszkańcy danej miejscowości mogą zgłaszać propozycje nazw, np. w drodze konkursu.

Na stronie internetowej miejscowości umieszczono Regulamin konkursu na nazwę głównej ulicy w Łuczycach. W § 4 wskazano zasady, jakich trzeba się trzymać, proponując nazwę: 


\section{$\S 4$}

\section{NAZWY ULIC}

1. Nazwy powinny odnosić się do konkretnej cechy, jaką wyróżnia się ulica. Może to być tradycyjna nazwa geograficzna (np. nazwa przysiółka, części wsi, pól), patronimiczna (związana z osobą zasłużoną dla społeczności lokalnej lub narodu), nazwa kierunkowa (określająca kierunek, miejscowość, dokąd prowadzi ulica), historyczna (odnosząca się do wydarzeń, postaci, miejsc, związanych z danym terenem).

2. Za patronów ulic nie można przyjmować osób żyjących. Nie powinno się także przyjmować za patronów osoby zmarłe niedawno (do 3 lat) lub osoby kontrowersyjne.

3. Nazwy nie mogą być trudne w codziennym użyciu (np. nazwy wielowyrazowe, niejasne lub stanowiące wyrażenia obce).

4. Nazwy nie mogą mieć charakteru ośmieszającego lub poniżającego.

Konkurs na nazwę fragmentu drogi powiatowej biegnącej przez gminę w kierunku Krakowa wygrała Krakowska (http://www.łuczyce-2db.pl/), a więc nazwa kierunkowa.

Od przełomu XIX i XX wieku rośnie liczba nazw pochodzących od antroponimów: nazwisk, imion, przezwisk. Widać to także w omawianych miastach najwięcej jest nazw ulic pochodzących od osobowych nazw własnych. W Bochni jest ponad 80 takich nazw ${ }^{5}$, w Dąbrowie Tarnowskiej ponad 30, w Tarnowie ponad $280^{6}$. Listę frekwencyjną najpopularniejszych aktualnych nazw ulic i placów opracowała Elżbieta Borysiak. Z jej badań wynika, że najpopularniejsza jest ulica Kościuszki, Mickiewicza znalazła się na trzecim miejscu po odapelatywnej Polnej (Borysiak 2007, s. 450-451).

Zjawiska i procesy społeczno-ekonomiczne zachodzące w XX i XXI wieku powodują poszerzanie się miast przez włączanie do nich okolicznych wsi lub ich części, a co za tym idzie - wykorzystywanie nazw włączonych wsi, przysiółków jako nazwy ulicy lub podstawy do jej utworzenia, np.: Kurów (od Kurów), Chodenicka (od Chodenice), Kolanowska (od Kolanów), Ulinów (od Ulinów), Gumniska (od Gumniska), Krzyska (od Krzyż), Strusińska (od Strusina). W Bochni i Tarnowie tego typu nazw jest więcej, na co wpływa przede wszystkim liczba wsi przyłączonych do danego miasta.

Nazwy derywowane od nazw miejscowości w tym przypadku nie są nazwami kierunkowymi, lecz nazwami wskazującymi nazwę dawnej wsi, osiedla, przysiół-

${ }^{5}$ Liczbę nazw ulic podaję w przybliżeniu, ponieważ jest ona zmienna, wciąż przybywa nowych nazw, zmieniane są też istniejące nazwy.

${ }^{6}$ Nazwy tarnowskich ulic powstałe od nazw osobowych omawiam w artykule Co nam mówiq nazwy ulic miast? (Data 2011). 
ka włączonych do miasta. W Bochni i Tarnowie tego typu nazw jest więcej, co wynika przede wszystkim z tego, ile wsi zostało przyłączonych do danego miasta i jakie zasady nadawania ulic były przyjęte w danym mieście. Na ogół zachowuje się nazwę przyłączonej miejscowości w postaci powielenia jej nazwy lub derywatu od niej. W Dąbrowie Tarnowskiej jest tylko jedna nazwa tego typu: Ulinów, wskazująca na włączenie sąsiedniej miejscowości w obręb miasta.

Ogólna liczba nazw ulic zależy oczywiście od wielkości miasta i liczby obiektów wymagających nazwania. Jest ich: ok. 665 w Tarnowie, 185 w Bochni i 70 w Dąbrowie Tarnowskiej. Jak wiadomo, na to, jakie typy nazw występują w danym mieście, mają wpływ różne czynniki: historyczne, polityczne, kulturowe oraz preferencje mieszkańców. Jakie typy nazw ulic reprezentowane są $\mathrm{w}$ omawianych miastach, pokazuję na wybranych przykładach w poniższej tabeli, stosując klasyfikację Handke (zob. przypis 2).

Jak wynika z tego zestawienia, w Tarnowie reprezentowane są wszystkie typy nazw ulic występujące w klasyfikacji opracowanej przez Handke (1992), w Bochni i Dąbrowie Tarnowskiej brak plateonimów pochodzących od nazw: etniczno-geograficznych, organizacji, gatunków zbóż, stanów emocjonalnych, pór roku, stanu pogody, tylko w Bochni nie ma nazwy ulicy od nazw owoców i warzyw oraz od historycznych bitew, z kolei tylko w Dąbrowie Tarnowskiej brak nazw odnoszących się do: podłoża ulicy, zwierząt, faktów historycznych. W Tarnowie dużo jest nazw przyrodniczych (ok. 90), metaforycznych (ok. 20), związanych $\mathrm{z}$ historią (ok. 30). W dwóch pozostałych miastach tych typów nazw jest mniej, np. w obydwu miastach razem nazw przyrodniczych jest tylko dziewięć, metaforycznych dwie, związanych z historią dziesięć (zob. tabela 1).

Charakterystyczną cechą dzisiejszego nazewnictwa miejskiego jest nadawanie nazw od nazw własnych osób związanych z danym miastem, pochodzących z niego, zasłużonych (zob. Borysiak 2007, Data 2011). W nazwach dawniejszych odbija się historia miasta, np. w Bochni są ulice mające łacińskie nazwy pochodzące od nazw szybów: Campi, Floris, Gazaris, Regis, Sutoris, Trinitatis. Związane jest to ze specyfiką miasta posiadającego jedną z najstarszych w Europie kopalnię soli. Trzy szyby przetrwały do dziś, a o trzech przypominają tylko nazwy ulic. W centrum Bochni zamontowano w 2013 roku 38 tabliczek z opisami 21 bocheńskich ulic ${ }^{7}$ (zob. aneks).

${ }^{7}$ Projekt umieszczenia tabliczek jest wynikiem współpracy: Wydziału Promocji i Rozwoju Miasta, Stowarzyszenia Bochniaków i Miłośników Ziemi Bocheńskiej, Muzeum im. Stanisława Fishera. 


\begin{tabular}{|c|c|c|c|c|c|c|c|c|c|c|}
\hline & 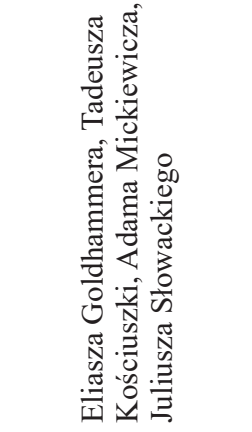 & 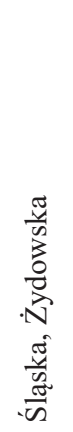 & 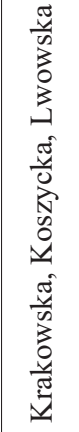 & 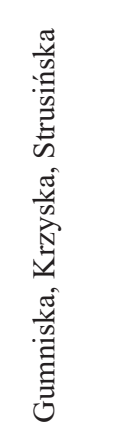 & 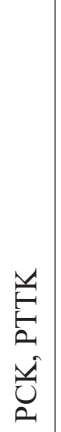 & & 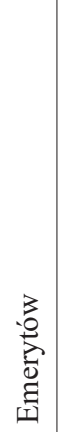 & 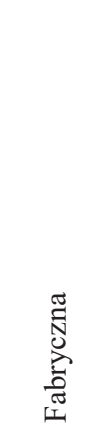 & & $\begin{array}{l}\text { N } \\
\text { Ẽ } \\
\text { N్ } \\
\text { D }\end{array}$ \\
\hline 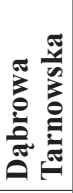 & 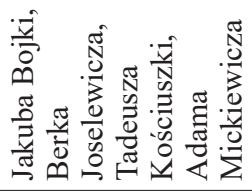 & 1 & 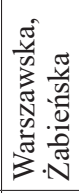 & $\begin{array}{l}3 \\
.3 \\
.3\end{array}$ & 1 & & $\begin{array}{l}3 \\
\frac{3}{0} \\
\frac{0}{0} \\
\frac{0}{0} \\
0 \\
\frac{0}{2}\end{array}$ & 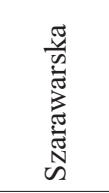 & & 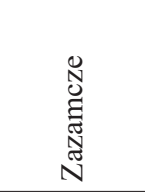 \\
\hline 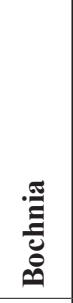 & 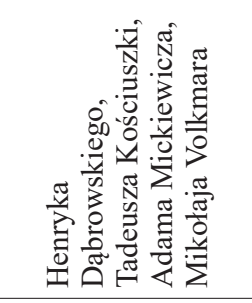 & 1 & 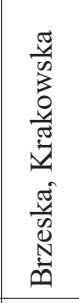 & 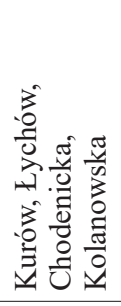 & 1 & & 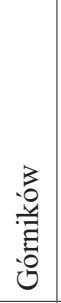 & 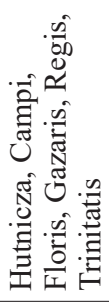 & & 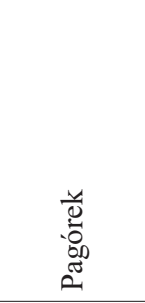 \\
\hline & & & & & & & & & & 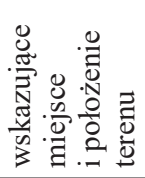 \\
\hline & 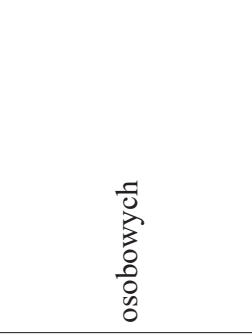 & 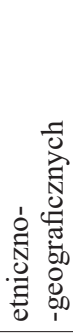 & 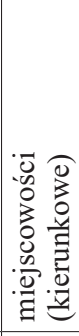 & 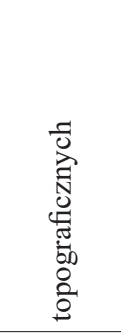 & 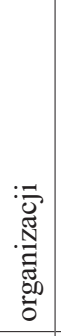 & & 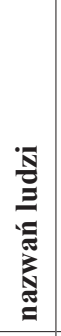 & 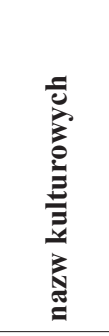 & 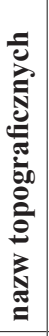 & \\
\hline & 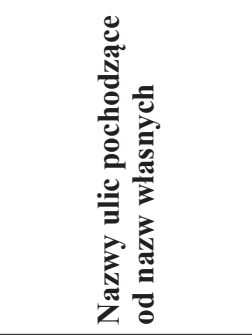 & & & & & 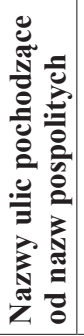 & & & & \\
\hline
\end{tabular}




\begin{tabular}{|c|c|c|c|c|c|c|c|c|c|c|}
\hline 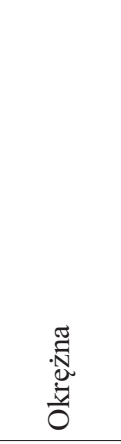 & $\frac{\tilde{\Xi}}{\stackrel{0}{0}}$ & 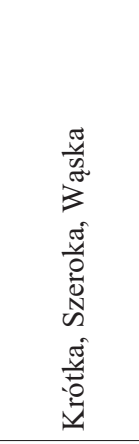 & & 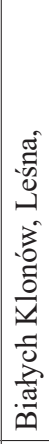 & 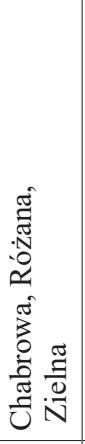 & 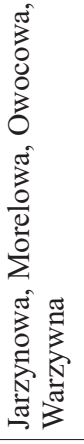 & 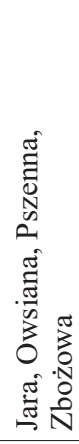 & 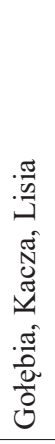 & & 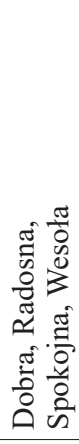 \\
\hline 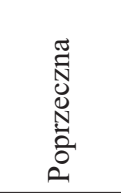 & $\mid$ & 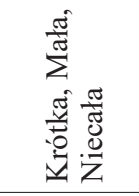 & & 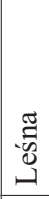 & 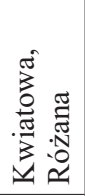 & 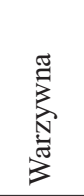 & $\mid$ & 1 & & 1 \\
\hline 劳 & $\underset{\tilde{E}}{\tilde{E}}$ & 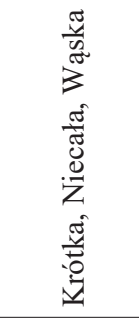 & & 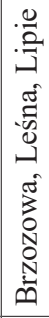 & 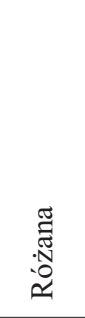 & 1 & 1 & 递 & & 1 \\
\hline 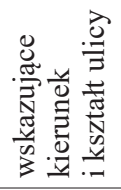 & 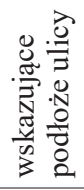 & 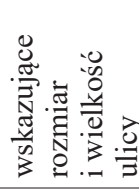 & & & & & & & & \\
\hline & & & & 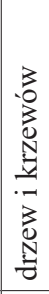 & 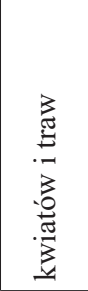 & $\begin{array}{l}3 \\
3 \\
0 \\
0 \\
3 \\
0 \\
3 \\
0 \\
0 \\
0 \\
0 \\
0\end{array}$ & 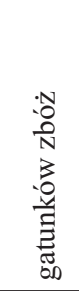 & . & & 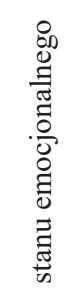 \\
\hline & & & 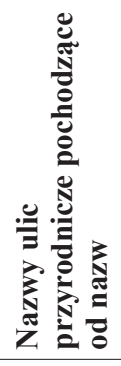 & & & & & & 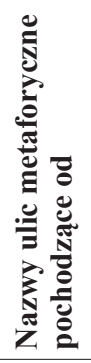 & \\
\hline
\end{tabular}




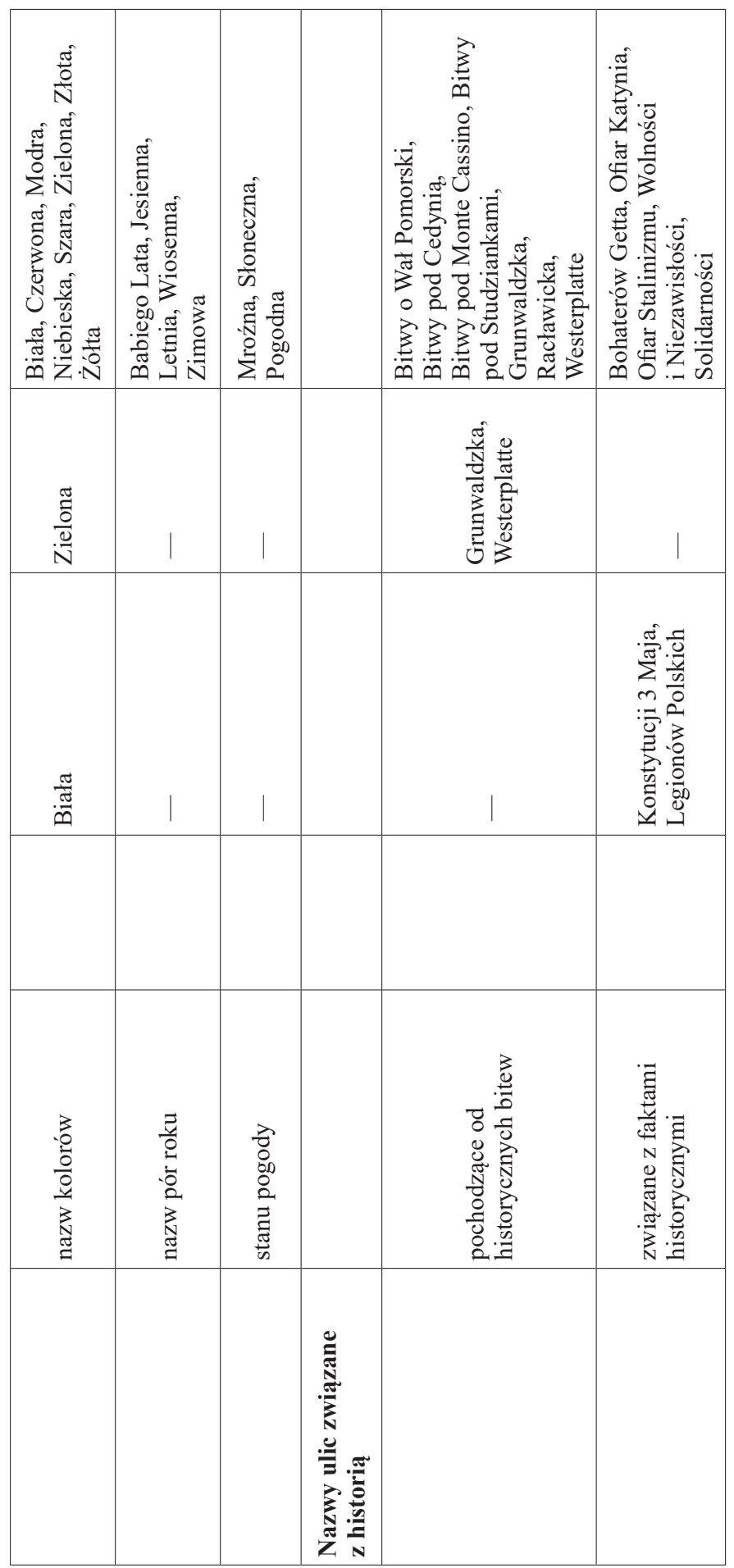




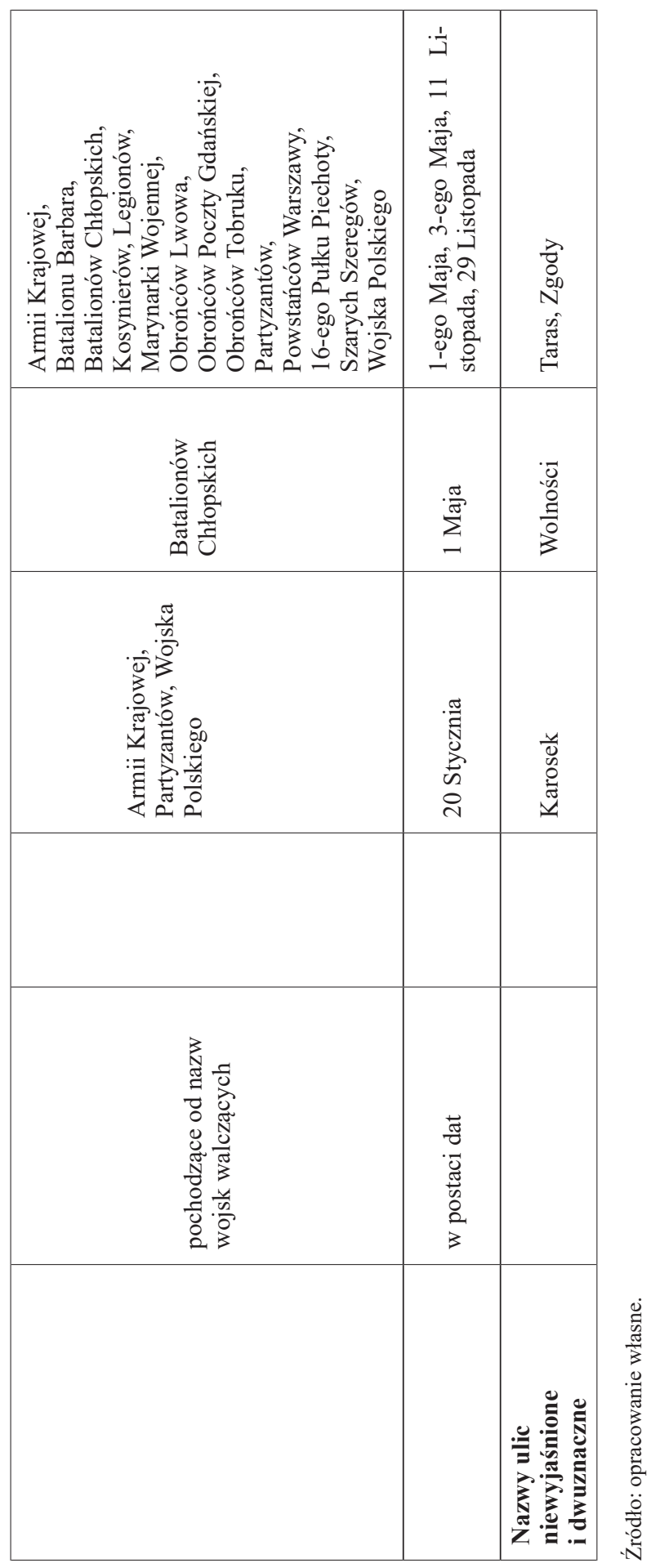


Tabliczki wykonane są ze szkła, umieszczone są na nich: herb miasta, logo 760. rocznicy lokacji i kod QR, historyczna fotografia fragmentu ulicy, nazwa ulicy i objaśnienie dotyczące jej pochodzenia w czterech językach: polskim, angielskim, rosyjskim i niemieckim. Dodatkowo w miejscu dawnego szybu Regis na początku ulicy została umieszczona tablica z obrazem przedstawiającym dawny szyb i z opisem jego historii (zob. aneks). Jak pisze autor artykułów o historii bocheńskich ulic, ,ich usytuowanie, kierunek, kształt i nazwy są świadectwem rozwoju organizmu miejskiego od XIII wieku" (Kobiela 2013, cz. 1, s. 7, podkreślenie moje - K.D.). Zdaniem Kobieli stare nazwy ulic powinny podlegać ochronie, podobnie jak zabytki. Na poparcie tego stwierdzenia autor przytacza opinię Handke (2011): ,jeśli nazwy obiektów przestrzeni miast średniowiecznych przetrwały, to stanowią bezcenny dokument historii każdego miasta. Jeśli zaś przetrwały nazwy (ulic), a zanikły obiekty, to dokumentacyjna wartość nazw jest tym cenniejsza".

Powyższe stwierdzenia odnoszą się nie tylko do miast średniowiecznych, lecz także do młodszych, które też mają w nazwach zapisaną swoją historię. W nazwach bocheńskich ulic widać górniczą historię miasta, związaną ze złożami soli kamiennej. Pokazują ją omówione już wyżej nazwy ulic pochodzące od nazw szybów oraz takie nazwy, jak: Solna, Solna Góra, Górników, Za Szybem. Z kolei nazwy Sadecka, Węierska mówią o szlaku handlowym przebiegającym przez Bochnię na Węgry. Jak już wspomniałam, w Bochni jest też kilka nazw ulic przeniesionych lub utworzonych od nazw miejscowych wsi włączonych do miasta w wyniku reform administracyjnych, podobnie jest w Tarnowie, w Dąbrowie Tarnowskiej jest tylko jedna taka nazwa. W plateonimach Tarnowa i Dąbrowy Tarnowskiej znajdziemy odniesienia do wielokulturowości, szczególnie do kultury żydowskiej, por. ulica Eliasza Goldhammera, który był zastępcą burmistrza Tarnowa, Berka Joselewicza — polskiego kupca pochodzenia żydowskiego, pułkownika Wojska Polskiego, oficera Legionów Polskich we Włoszech, Bóżnic czy Żydowska. Także w Dąbrowie Tarnowskiej jest ulica Berka Joselewicza. W Tarnowie w nazwach ulic znajdujemy również ślady związków z Węgrami, np. skwer Sandora Petöfiego — poety węgierskiego, ideowego przywódcy rewolucji 1848-1849, ulicę Józefa Antalla - polityka węgierskiego. Na podkreślanie związku Węgrów z Tarnowem wpływ miało na pewno to, że w Tarnowie urodził się Józef Bem (1794-1850), który w powstaniu węgierskim (1848-1849) dowodził wojskami węgierskimi, a tarnowianie jego imieniem nazwali ulicę i plac.

Aspekty kulturowe w nazewnictwie miejskim odnoszą się z jednej strony do zewnętrznych i kulturowych uwarunkowań nadawania nazw ulicom i do ich $z_{\text {zmian }}^{8}$, a z drugiej pokazują kulturowy obraz miast.

8 Ciekawym zagadnieniem kulturowym, które wymaga oddzielnych opracowań, są przyczyny i kierunki zmian istniejących plateonimów. W historii miast nazwy ulic były zmieniane czasem nawet kilka razy. 


\section{Bibliografia}

Antkowiak Z. (1970), Ulice i place Wrocławia, Wrocław.

Borysiak E. (2007), Najczęściej występujące w polskich miastach nazwy ulic, [w:] Nowe nazwy własne - tendencje badawcze, red. A. Cieślikowa, B. Czopek-Kopciuch, K. Skowronek, Kraków, s. 449-456.

Buczyński M. (1966), Nazwy ulic i placów Lublina, „Onomastica” 11, s. 136-181.

Data K. (2012), Co nam mówiq nazwy ulic miast?, [w:] Mundus verbi, in honorem Sophiae Cygal-Krupa, red. M. Pachowicz, K. Choińska, Tarnów, s. 86-92.

Handke K. (1970), Semantyczne i strukturalne typy nazw ulic Warszawy, Wrocław.

Handke K. (1992), Polskie nazewnictwo miejskie, Warszawa.

Handke K. (2005), Nazewnictwo miejskie, [w:] Polskie nazwy własne. Encyklopedia, red. E. Rzetelska-Feleszko, Kraków, s. 283-307.

Handke K. (2011), Dzieje Warszawy nazwami pisane, Warszawa.

Jancewicz B., Smółka L. (red.) (2000), Nazwy ulic Wrocławia, Wrocław.

Kobiela S. (2013), Bocheńskie ulice, „Wiadomości Bocheńskie. Kwartalnik Stowarzyszenia Bochniaków i Miłośników Ziemi Bocheńskiej”, cz. 1, nr 3 (96), s. 7-15; cz. 2, nr 4 (99), s. 30-36; cz. 3, nr 1 (100), s. 16-21; cz. 4, nr 2 (101), s. 36-38.

Kobiela S. (2014), Bocheńskie ulice w latach 1945-56, „Wiadomości Bocheńskie. Kwartalnik Stowarzyszenia Bochniaków i Miłośników Ziemi Bocheńskiej”, nr 4 (103), s. 15-22, wersja elektroniczna on-line: http://www.bochniacy.pl/.

Mrózek R. (2004), Nazwy własne jako przedmiot badawczy onomastyki, [w:] Nazwy własne w języku, kulturze i komunikacji społecznej, red. R. Mrózek, Katowice, s. 7-19.

Myszka A. (2013), Spoleczne i kulturowe przyczyny powstawania paralelnych urbanonimów nieoficjalnych - na przykładzie nazw rzeszowskich (XVIII-XX w.), „Słowo. Studia Językoznawcze" 4, red. K. Ożóg, Rzeszów, s. 103-115, wersja elektroniczna on-line: ifp.univ.rzeszow.pl/ slowo/slowo_4/myszka.pdf.

Myszka A. (2014), Struktura wyrazu jako wskaźnik proprialności w toponimii (na przykładzie zapisów z osiemnastowiecznych ksiag sądowych Rzeszowa), „Onomastica” LVIII, s. 151-166.

Myszka A., Wisz P. (2012), Nazwy ulic Rzeszowa. Historia i wspótczesność, Rzeszów.

Nowak F. (1989), Semantyczne i stowotwórcze typy nazw ulic Bydgoszczy, [w:] Nazewnictwo miejskie, red. S. Urbańczyk, Poznań, s. 139-150.

Orłoś T. (2010), Nazwy praskich placów, [w:] Język polski - wczoraj, dziś, jutro, red. B. Czopek-Kopciuch, red. P. Żmigrodzki, Kraków, s. 339-347.

Oronowicz-Kida E. (2014), Oficjalne nazwy wiejskich ulic w województwie podkarpackim. Studium językowo-kulturowe, Rzeszów.

Rzetelska-Feleszko E. (2006), W świecie nazw własnych, Warszawa-Kraków.

Rzetelska-Feleszko E. (2007), Onomastyka kulturowa, [w:] Nowe nazwy własne - tendencje badawcze, red. A. Cieślikowa, B. Czopek-Kopciuch, K. Skowronek, Kraków, s. 57-62.

Supranowicz E. (1995), Nazwy ulic Krakowa, Kraków.

Šrámek R. (2010), Struktura relacji 'nazwa własna - rzeczywistość', [w:] Nazwy własne a społeczeństwo, t. 1, red. R. Łobodzińska, Łask, s. 23-31.

Urbańczyk S. (red.) (1998), Nazewnictwo miejskie, Poznań. 


\section{Strony internetowe (dostęp: 30 czerwca 2015)}

bochnia.eu/pl/turystyka/21_Przewodnik-po-miescie/65_Atrakcje/bochenskie-ulice.html. http://mapa.nocowanie.pl/bochnia/ulice/. http://mapa.nocowanie.pl/dabrowa_tarnowska/ulice/. http://mapa.nocowanie.pl/tarnow/ulice/.

http://www.łuczyce-2db.pl/ulice/konkurs-na-nazwe-glownej-ulicy, dostęp: 10 kwietnia 2014 i 30 czerwca 2015.

www.it.tarnow.pl/index.php/pol/Atrakcje/TARNOW/Ciekawostki/Ulice-nowe-i-stare-nazwy oprac. Marcin Pałach, Tarnowskie Centrum Informacji, 30 sierpnia 2007, ostatnia aktualizacja: 17 czerwca 2015.

\section{Cultural conditioning of street names tradition and changes}

\section{Summary}

The article deals with the problem of the cultural conditioning of street names as well as the changes in a method and scope of onomastic research. The author discusses street names given both in the past and at present paying much attention to the specificity of the underlying basis and motivation of the choice faced. The changes of the existing names of the streets and their origins are also described. The analysis is based on the material collected among the street names in Tarnów juxtaposed with the ones in Bochnia and Dąbrowa Tarnowska. The historical perspective is helpful both in selecting certain street name types predominating in the past and at present and indicating what the changes in the names refer to.

Keywords: street name, cultural onomastic 


\section{Aneks}

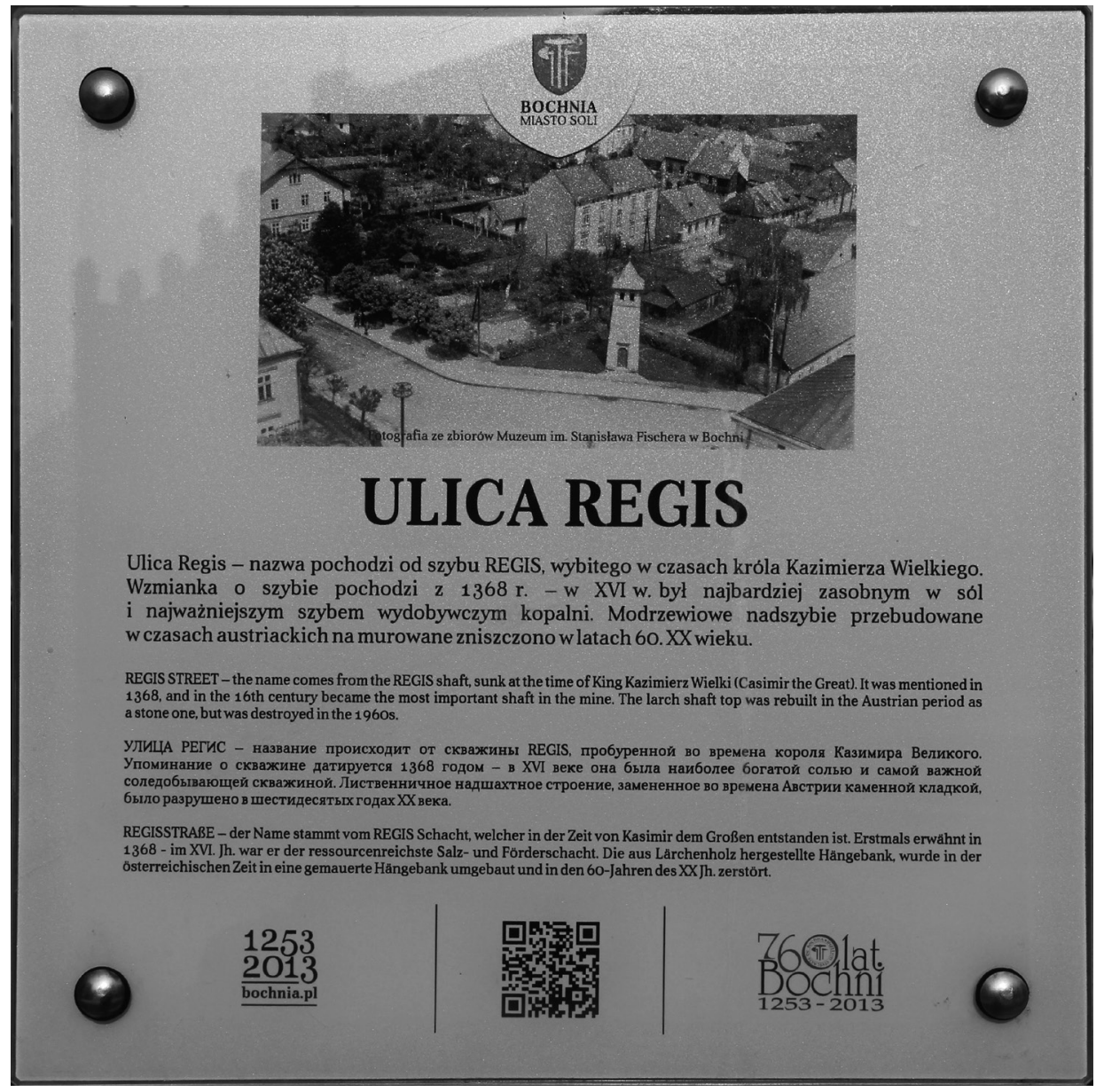

Fot. 1. Tabliczka z opisem ulicy Regis w Bochni 


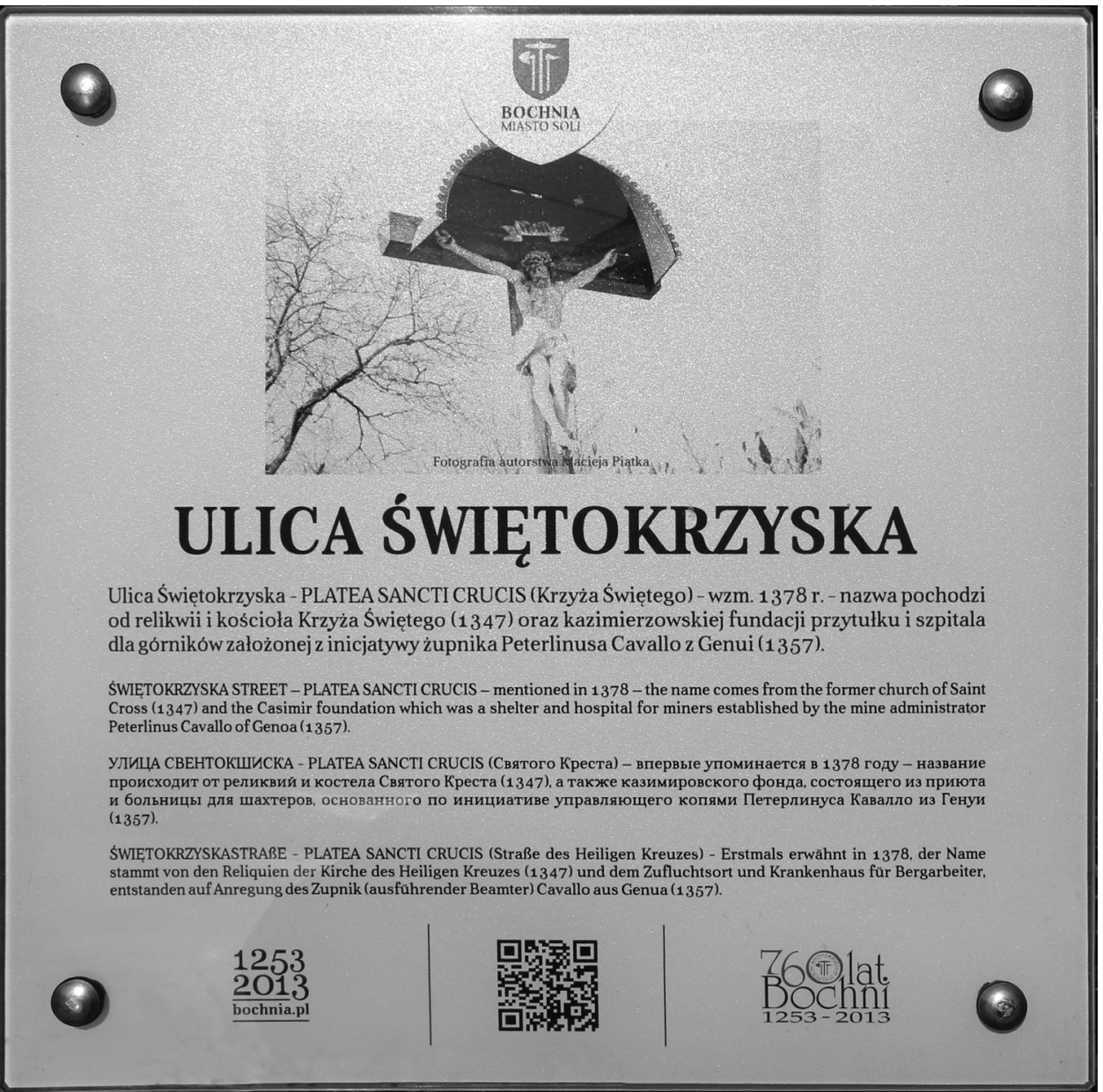

Fot. 2. Tabliczka z opisem ulicy Świętokrzyskiej w Bochni 


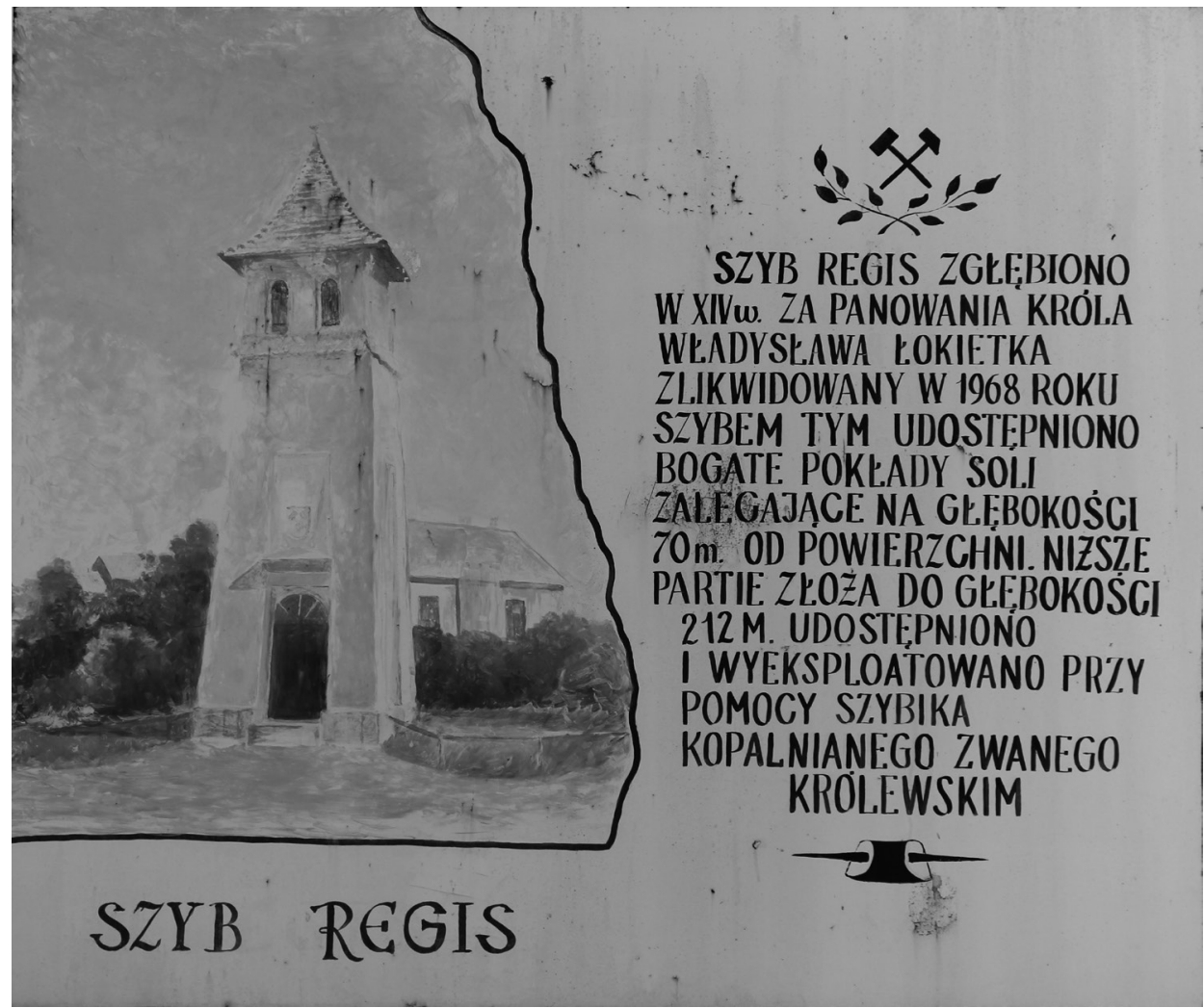

Fot. 3. Tablica z obrazem nieistniejącego już szybu Regis i jego historią stojąca na początku ulicy Regis w Bochni 